\title{
MENYUSUI EKSKLUSIF, PENYAKIT DIARE DENGAN KEJADIAN STUNTING PADA ANAK BALITA USIA 24-59 BULAN DI WILAYAH KERJA PUSKESMAS SANGKUB
}

\author{
Rivolta G.M.Walalangi ${ }^{1}$, Olfie Sahelangi ${ }^{2}$, Rudolf B.Purba ${ }^{3}$ Dan Nilam \\ Sentika ${ }^{4}$ \\ Jurusan Gizi Poltekkes Kemenkes Manado \\ Email korespondensi: acha308@gmail.com
}

\begin{abstract}
Stunting is a chronic condition of a child's poor linear growth which is an accumulation of the effects of various factors such as poor nutrition and health before and after the birth of the child. Riskesdas data in 2013 amounted to $37.2 \%$ of Indonesian children experiencing stunting. This figure increased compared to $2010(35.6 \%)$ and 2007 (36.8\%). This study was conducted to analyze exclusive breastfeeding status and diarrheal disease as risk factors for stunting in children under the age of 24-59 months in the working area of Sangkub Community Health Center, Sangkub Subdistrict, Bolaang Mongondow Utara Regency. This type of research is Analytical Observational with a Retrospective Cohort design. Conducted in January - February 2019 in the working area of the Sangkub Community Health Center, Sangkub District, North Bolaang Mongondow Regency. with a sample size of 40 toddlers. The sampling technique is consecutive sampling. The results showed that the results of statistical tests using the Fisher's Exact Test test obtained a significant level $(p=0.037)$ which means $p=<0.05$. From these results it can be seen that there is a significant relationship between exclusive breastfeeding status and the incidence of stunting in infants aged 24-59 months in the working area of Sangkub Community Health Center, Sangkub Subdistrict, North Bolaang Mongondow Regency and obtained a significant level $(p=1,000)$ means $p=>0.05$, which means that there is no significant relationship between diarrheal disease and the incidence of stunting in infants aged 24-59 months in the working area of Sangkub Community Health Center, Sangkub District, North Bolaang Mongondow Regency.
\end{abstract}

\section{Keywords: Exclusive Breastfeeding Status, Diarrhea, and Stunting}

Salah satu tantangan utama yang saat ini dihadapi sektor kesehatan di Indonesia adalah kekurangan gizi kronis pada anak. Meskipun banyak perkembangan dan kemajuan kesehatan telah dilakukan di Indonesia selama beberapa tahun terakhir, namun masalah stunting tetap signifikan. World Health Organization (WHO) pada tahun 2016 mencatat bahwa ada 87 juta anak stunting terdapat di Asia, 59 juta di Afrika dan 6 juta di Amerika Latin dan wilayah Karibia. (WHO, 2018). Menurut hasil Pemantauan Status Gizi (PSG) tahun 2017 status gizi balita di Indonesia berdasarkan Indeks TB/U sebanyak $9,8 \%$ balita dengan status gizi sangat pendek dan $19,8 \%$ balita 
dengan status gizi pendek. Persentase stunting/pendek (sangat pendek+pendek) pada kelompok balita $(29,6 \%)$ lebih tinggi dibandingkan kelompok baduta $(20,1 \%)$.

Di beberapa negara berkembang, menurut Lamberti, dkk bahwa kurangnya pemberian ASI eksklusif sampai 6 bulan dan kekurangan ASI pada bayi umur 6-23 bulan berhubungan dengan risiko infeksi diare yang lebih tinggi, dan berhubungan dengan kesakitan dan kematian (Patimah, 2017). Selanjutnya hasil penelitian Lestari, dkk (2014) menunjukkan bahwa faktor risiko kejadian stunting antara lain menderita diare, dan tidak diberi ASI eksklusif pada usia 6-24 bulan di Kecamatan Penanggalan Kota Subulussalam Provinsi Aceh.

Hasil Riskesdas tahun 2013 sejumlah 37,2\% anak Indonesia mengalami stunting. Angka ini meningkat dibandingkan 2010 (35,6\%) dan 2007 (36,8\%). Stunting, yang terjadi selama masa anak-anak sebagai akibat dari kekurangan gizi kronis, memengaruhi kemampuan kognitif dan mengurangi potensi akses ke pendapatan yang lebih tinggi, risiko melahirkan bayi dengan berat badan lahir rendah, dan jangka hidup yang lebih pendek. Stunting disebabkan oleh 4 masalah utama yaitu faktor keluarga dan rumah tangga, pemberian makanan tambahan yang tidak adekuat, pemberian ASI, serta penyakit infeksi (Fikawati dkk, 2017).

Menurut Desyanti dan Nindya (2017) dalam penelitiannya ada hubungan yang signifikan antara riwayat penyakit diare dengan kejadian stunting pada balita usia 2459 bulan di wilayah kerja Puskesmas Simolawang, Surabaya. Hasil penelitian Kusumawati dkk (2015) menunjukkan tiga faktor yang secara bersama-sama mempengaruhi stunting anak usia enam sampai 36 bulan, yaitu penyakit infeksi, ketersediaan pangan dan sanitasi lingkungan dan yang paling dominan adalah penyakit infeksi paling sering dialami adalah ISPA dan diare. Penelitian Candra M dkk (2016) Determinan kejadian stunting pada bayi usia 6 bulan adalah tingkat ekonomi keluarga, kejadian ISPA, kejadian diare, berat badan lahir, dan tingkat pendidikan ibu.

Di provinsi Sulawesi Utara hasil penilaian status gizi balita berdasarkan Indeks TB/U tahun 2017 sebesar 14,1\% sangat pendek dan 17,3\% Pendek. Kabupaten Bolaang Mongondow Utara merupakan salah satu kabupaten di Provinsi Sulawesi Utara sebesar $36.8 \%$ dari hasil penilaian status gizi balita yang mengalami stunting (Kemenkes RI, 2017). Berdasarkan uraian di atas, peneliti tertarik untuk melakukan penelitian tentang status menyusui eksklusif dan penyakit diare dengan kejadian stunting pada anak berusia 24-59 bulan di wilayah kerja Puskesmas Sangkub Bolaang Mongondow Utara tahun 2018.

\section{METODE}

Jenis penelitian ini adalah penelitian observasional analitik dengan rancangan penelitian Kohort Retrospektif. Penelitian ini menggambarkan hubungan status menyusui eksklusif dan penyakit diare dengan kejadian stunting pada anak balita usia 24-59 bulan di Desa Sangkub Bolaang Mongondow Utara. Penelitian dilaksanakan di 
wilayah kerja puskesmas Sangkub. Populasi dalam penelitian ini adalah anak balita usia 24-59 bulan di wilayah kerja Puskesmas Sangkub Kabupaten Bolaang Mongondow Utara. Teknik pengambilan sampel pada penelitian ini dilakukan secara non probability sampling dengan tipe consecutive sampling yaitu setiap sampel yang memenuhi kriteria penelitian dimasukkan dalam penelitian sampai kurun waktu tertentu, sehingga jumlah pasien ynag diperlukan terpenuhi.

Pengumpulan data dengan wawancara menggunakan kuesioner setelah melakukan pengukuran tinggi badan yang kemudian dimasukkan ke format master tabel. Analisa data pada penelitian ini terdiri dari Univariat dan Bivariat, dengan uji statistik menggunakan Uji Chi Square.

HASIL

Tabel 1. Distribusi Frekuensi Karakteristik Ibu Balita terdiri dari Umur, Pendidikan, Pekerjaan dan pengetahuan.

\begin{tabular}{cccc}
\hline Umur Ibu (Tahun) & n & \% \\
& $<29$ & 15 & 37,5 \\
& $29-38$ & 22 & 55 \\
& $>38$ & 3 & 7,5 \\
Pendidikan Ibu & & \\
$\begin{array}{l}\text { Rendah (Tidak tamat SD, SD, SLTP) } \\
\text { Tinggi (SLTA \& Akademik/Perguruan tinggi }\end{array}$ & 30 & 75.0 \\
$\begin{array}{l}\text { Pekerjaan Ibu } \\
\text { Bekerja (PNS, Peg. Swasta, Petani, }\end{array}$ & 10 & 25.0 \\
$\quad$ Wiraswasta) & 5 & 12.5 \\
Ibu Rumah Tangga & 35 & 87.5 \\
Pengetahuan Ibu & & \\
$\quad$ Baik & 21 & 52.5 \\
Kurang & 19 & 47.5 \\
\hline
\end{tabular}

Umur sebagian besar responden dalam penelitian ini berkisar tahun 29-38 tahun, dengan pendidikan terakhir responden sebagian besar adalah SD, sebagian besar tidak bekerja dan pengetahuan baik yang dimiliki responden lebih tinggi sedikit dibandingkan dengan yang berpengetahuan kurang. 
Tabel 2. Distribusi Frekuensi Karakteristik Balita Umur 24-59 Bulan (Umur dan Jenis Kelamin)

\begin{tabular}{ccc}
\hline Karakteristik & $\mathbf{n}$ & $\mathbf{\%}$ \\
\hline Umur Balita (bulan) & & \\
\hline $24-35$ & 15 & 37,5 \\
$36-47$ & 12 & 30 \\
$48-59$ & 13 & 32,5 \\
Jenis Kelamin & & \\
Laki-laki & 21 & 52,5 \\
Perempuan & 19 & 47,5 \\
\hline
\end{tabular}

Dari hasil penelitian didapatkan, sebanyak $52,5 \%$ balita berjenis kelamin perempuan dan sebagian besar berumur di sekitar usia 24 - 35 bulan.

Tabel 3. Distribusi Frekuensi Balita Berdasarkan Status Menyusui Ekslusif

\begin{tabular}{ccc}
\hline Status Menyusui Eksklusif & $\mathbf{n}$ & $\%$ \\
Mendapat ASI eksklusif & 12 & 30.0 \\
Tidak Mendapat ASI eksklusif & 28 & 70.0 \\
\hline
\end{tabular}

Hasil penelitian menunjukkan bahwa sampel yang tidak mendapat ASI eksklusif berjumlah 28 anak (70\%).

Tabel 4. Distribusi Frekuensi Balita Berdasarkan Frekuensi Diare Dalam Sehari

\begin{tabular}{ccc}
\hline Frekuensi Diare Dalam Sehari & $\mathbf{n}$ & $\%$ \\
Sehari $>3$ kali & 27 & 67.5 \\
Sehari $<3$ kali & 13 & 32.5 \\
\hline
\end{tabular}

Hasil penelitian menunjukkan bahwa sebagian besar sampel yang mempunyai frekuensi diare dalam sehari $>3$ kali berjumlah 27 orang $(67.5 \%)$.

Tabel 5. Distribusi Frekuensi Balita Berdasarkan Stunting

\begin{tabular}{ccc}
\hline Kategori Stunting & $\mathrm{n}$ & $\%$ \\
\hline Pendek & 31 & 77.5 \\
Sangat Pendek & 9 & 22.5 \\
\hline
\end{tabular}


Hasil penelitian menunjukkan bahwa balita yang mengalami stunting sebagian besar dengan kategori pendek 31 orang $(77,5 \%)$.

Tabel 6. Hubungan Status Menyusui Eksklusif Dengan Stunting

\begin{tabular}{|c|c|c|c|}
\hline \multirow{2}{*}{ Status Menyusui Eksklusif } & \multicolumn{2}{|c|}{ Stunting } & \multirow{2}{*}{$\boldsymbol{P}$} \\
\hline & Pendek & Sangat Pendek & \\
\hline \multirow{2}{*}{$\begin{array}{c}\text { Mendapat ASI eksklusif } \\
\text { Tidak Mendapat ASI } \\
\text { eksklusif }\end{array}$} & 12 & 0 & \multirow[b]{2}{*}{$0,037^{*}$} \\
\hline & 19 & 9 & \\
\hline
\end{tabular}

Berdasarkan tabel 6 diatas dapat diketahui terdapat 12 orang yang mendapat ASI eksklusif dengan stunting kategori pendek, 0 orang yang mendapat ASI eksklusif dengan stunting kategori sangat pendek, 19 orang yang tidak mendapat ASI eksklusif dengan stunting kategori pendek, 9 orang yang tidak mendapat ASI ekslusif dengan stunting kategori sangat pendek.

Tabel 7. Hubungan Frekuensi Diare dengan Stunting

\begin{tabular}{|c|c|c|c|}
\hline \multirow{2}{*}{ Frekuensi Diare } & \multicolumn{2}{|c|}{ Stunting } & \multirow{2}{*}{$P$} \\
\hline & Pendek & Sangat Pendek & \\
\hline Sehari >3 kali & 21 & 6 & 1000 * \\
\hline Sehari $<3$ kali & 10 & 3 & 1.000 \\
\hline
\end{tabular}

Terdapat 21 orang yang memiliki riwayat penyakit diare sehari $>3$ kali dengan stunting kategori pendek, 6 orang yang memiliki riwayat penyakit diare sehari $>3$ kali dengan stunting kategori sangat pendek, 10 orang yang memiliki riwayat penyakit diare sehari $<3$ kali dengan stunting kategori pendek dan 3 orang yang memiliki riwayat penyakit diare sehari $<3$ kali dengan stunting kategori sangat pendek.

\section{PEMBAHASAN}

Terdapat hubungan yang bermakna antara status menyusui eksklusif dengan kejadian stunting. Dari hasil penelitian bahwa yang tidak mendapat ASI eksklusif lebih berisiko mengalami stunting. Berdasarkan tabel 6, Hasil Fisher's Exact Test menunjukan Nilai $p=0,037(p<0,05)$, Maka dapat disimpulkan bahwa tidak ada hubungan yang bermakna antara status menyusui eksklusif dengan kejadian stunting.

Hal ini sejalan dengan penelitian Pangalila, dkk (2018) yang dilakukan di Kabupaten Minahasa, hasil analisis hubungan antara riwayat pemberian ASI eksklusif 
dengan stunting di dapatkan hasil uji statistik dengan nilai sebesar $(p=0,017)$ yang menjukkan adanya hubungan, diperoleh bahwa sebanyak $19(21,1 \%)$ bayi yang tidak menerima ASI eksklusif menderita stunting sedangkan yang tidak menderita stunting sebanyak 41 (45,6\%). Penelitian Dwitama, dkk (2018) juga mendapat hasil bahwa terdapat hubungan antara pemberian ASI eksklusif dengan balita pendek.

Berbeda dengan penelitian yang dilakukan oleh Halim, dkk (2018) hasil uji statistik hubungan didapatkan nilai $p$ sebesar $(p=0,062)$, maka secara statistik tidak terdapat hubungan bermakna antara ASI eksklusif dengan kejadian stunting. Berdasarkan penelitian chairani dkk tentang gambaran pemberian asi eksklusif terhadap kejadian stunting pada balita umur 24-60 bulan di kelurahan tanah baru Bogor tahun 2018 bahwa tidak ada hubungan yang signifikan antara pemberian ASI eksklusif dengan kejadian stunting.

Tidak terdapat hubungan yang bermakna antara penyakit diare dengan stunting $(p>0,05)$. Tidak ada hubungan yang bermakna antara terdapat hubungan yang signifikan antara penyakit diare dengan kejadian stunting $(p>0,05)$..

Hal ini sejalan dengan penelitian yang dilakukan oleh Lestari (2016) hasil uji statistik hubungan didapatkan nilai $p$ sebesar $(p=0,851)$, maka secara statistik tidak terdapat hubungan bermakna antara riwayat diare dan kejadian stunted. Berbeda dengan penelitian yang dilakukan oleh Angkat (2018) faktor yang memengaruhi kejadian stunting di Kecamatan Simpang Kiri pada anak usia 12-36 bulan adalah penyakit diare. Hasil uji statistik dengan menggunakan uji chi-square diperoleh nilai $p$ $<0,05$ menunjukkan bahwa ada pengaruh riwayat kejadian diare dengan terjadinya stunting. Hasil penelitian yang berbeda jika dibandingkan dengan penelitian Angkat (2018) adalah karena keterbatasan dalam jumlah sampel, penelitian Angkat memiliki jumlah sampel 106 anak.

Penyebab langsung stunting adalah kurangnya asupan zat gizi dan seringnya peristiwa sakit, terutama diare, pada anak. Status gizi anak berkaitan erat dengan infeksi yang diderita anak. Studi di Bangladesh dan Guatemala menunjukkan adanya hubungan timbal balik antara status gizi dengan peristiwa sakit karena infeksi pada anak. Meskipun frekuensi sakit lebih ditentukan oleh besarnya populasi bakteri pathogen di lingkungan, namun keparahan dan lamanya sakit ditentukan oleh status gizi. Bila terkena infeksi, anak dengan gizi baik sakitnya tidak begitu parah dan lebih lekas sembuh, dibanding dengan anak dengan gizi kurang (Fikawati dkk, 2017).

\section{KESIMPULAN}

Terdapat hubungan yang bermakna antara status menyusui eksklusif dengan kejadian stunting pada balita umur 24 - 59 bulan di Puskesmas Sangkub. Tidak terdapat hubungan yang bermakna antara frekuensi diare, pendidikan dan pengetahuan ibu dengan kejadian stunting pada balita umur $24-59$ bulan di 
Puskesmas Sangkub. Disarankan agar penyuluhan ASI eksklusif dan diare lebih ditingkatkan dan pemantauan status gizi stunting terus dilakukan.

\section{DAFTAR PUSTAKA}

AL-Rahmad, H.A. Miko, A. \& Hadi, A. (2013) Kajian Stunting Pada Anak Balita Ditinjau Dari Pemberian ASI Eksklusif, MP-ASI, Status Imunisasi Dan Karakteristik Keluarga di kota Banda Aceh. Jurnal Kesehatan IImiah Nasuwakes 6 (2 : 182183)

Andriani, R. (2019) Pencegahan Pencegahan Kematian Ibu Saat Hamil dan Melahirkan Berbasis Komunitas. Deepublish. Yogyakarta.

Angkat, A. H. (2018) Penyakit Infeksi Dan Praktek Pemberian MP-ASI Terhadap Kejadian Stunting Pada Anak Usia 12-36 Bulan Di Kecamatan Simpang Kiri Kota Subulussalam. Jurnal Dunia Gizi $1(1: 54)$

Aridiyah, F. O. Rohmawati, N. \& Ririanty, M. (2015). Faktor-faktor yang Mempengaruhi Kejadian Stunting pada Anak Balita di Wilayah Pedesaan dan Perkotaan. eJurnal Pustaka Kesehatan. $3(1: 169)$

Candra, M. A. Subagio, H. W. \& Margawati, A. (2016) Determinan kejadian stunting pada bayi usia 6 bulan di kota Semarang. Jurnal Gizi Indonesia 4 ( $2: 87$ )

Chairani, L. S. dkk. (2018) Gambaran Pemberian Asi Eksklusif Terhadap Kejadian Stunting Pada Balita Umur 24-60 Bulan Di Kelurahan Tanah Baru Bogor Tahun 2018. Promotor Jurnal Mahasiswa Kesehatan Masyarakat. 2 ( $2: 127$ )

Desyanti, C. \& Nindya, T. S. (2017). Hubungan Riwayat Penyakit Diare dan Praktik Higiene dengan Kejadian Stunting pada Balita Usia 24-59 Bulan di Wilayah Kerja Puskesmas Simolawang, Surabaya. Amerta Nutrition. 1 (3: 249 )

Dwitama, Y. S. Zuhairini, Y. \& Djais, J. (2018). Hubungan Pemberian ASI Eksklusif dan Makanan Pendamping ASI terhadap Balita Pendek Usia 2 sampai 5 tahun di Kecamatan Jatinangor. JSK. 3 ( $3: 147$ )

Fikawati, S. dkk. (2015). Gizi Ibu dan Bayi. PT RajaGrafindo Persada, Jakarta

Fikawati, S. dkk. (2017). Gizi Anak dan Remaja. PT RajaGrafindo Persada, Jakarta

Fitri, L. (2018). Hubungan BBLR dan ASI ekslusif dengan Kejadian Stunting di Puskesmas Lima Puluh Pekanbaru. 3 (1:136)

Halim, L. A. Warouw, S. M. \& Manoppo J. I. C. (2018). Hubungan Faktor-Faktor Risiko Dengan Stunting Pada Anak Usia 3-5 Tahun Di Tk/Paud Kecamatan Tuminting. Jurnal Medik dan Rehabilitasi (JMR), 1 ( $2: 6$ )

Irianto, K. (2014). IImu Kesehatan Anak. Alfabeta, Bandung

Jumadil. \& Landung, J (2015) Analisis Faktor-Faktor Berhubungan Dengan Kejadian Diare Pada Balita di Puskesmas Mungkajang Kota Palopo. Akademi Keperawatan Sawerigading Pemda Luwu. 
Kementrian Kesehatan (2011). Keputusan Menteri Kesehatan Republik Indonesia No:1995/MENKES/SK/XII/2010 tentang Standar Antropometri Penilaian Status Gizi Anak. Direktorat Bina Gizi,

Kementrian Kesehatan (2016). Pusat Data dan Informasi Situasi Balita Pendek. Jakarta Selatan: Kementrian Kesehatan Republik Indonesia. RI. http://www.depkes.go.id/resources/download/pusdatin/infodatin/situasi-balitapendek-2016.pdf. Diakses tanggal 4 april 2018

Kementrian Kesehatan Republik Indonesia. PSG 2017. Jakarta. http://www.kesmas.kemkes.go.id/assets/upload/dir 519d41d8cd98f00/files/Bu ku-Saku-Nasional-PSG-2017 975.pdf diakses pada 13 april 2018

Kusumawati, E Rahardjo, S \& Permata, S. H. (2015) Model Pengendalian Faktor Risiko Stunting Pada Anak. Jurnal Kesehatan Masyarakat Nasional. 9 (3: 255)

Lestari. (2016). Faktor Risiko Kejadian Stunted Pada Anak Usia 7-24 Bulan di Desa Hargorejo, Kecamatan Kokap, Kabupaten Kulonprogo, Yogyakarta. Program studi ilmu gizi Universitas Muhammadiyah Surakarta. Yogyakarta.

Lestari, W. Ani, M. \& Rahfiludin, M.Z. (2014). Faktor Risiko Stunting Pada Anak Umur 6-24 Bulan Di Kecamatan Penanggalan Kota Subulussalam Provinsi Aceh. Jurnal Gizi Indonesia. $3(1: 43)$

Mentari, S. \& Hermansyah, A. (2018). Faktor-Faktor Yang Berhubungan Dengan Status Stunting Anak Usia 24-59 Bulan di Wilayah kerja UPK Puskesmas Siantan Hulu. Pontianak Nutrition Journal (PNJ). 1 (1:4)

Ni'mah, C \& Muniroh, L (2015) Hubungan Tingkat Pendidikan, Tingkat Pengetahuan dan Pola Asuh Ibu Dengan Wasting Dan Stunting pada Balita Keluarga Miskin. Media Gizi Indonesia. $10(1: 89)$

Ni'mah, K. \& Nadhiroh, S. R. (2015). Faktor Yang Berhubungan Dengan Kejadian Stunting Pada Balita. Media gizi Indonesia. 10 (1:18)

Nugroho, A. (2016) Determinan Growth Failure (Stunting) Pada Anak Umur 1 s/d 3 Tahun (Studi Di Kecamatan Tanjungkarang Barat Kota Bandar Lampung). Jurnal Kesehatan. 7 (3:477)

Olsa, E. D. Sulastri, D \& Anas, E. (2017) Hubungan Sikap dan Pengetahuan Ibu Terhadap Kejadian Stunting pada Anak Baru Masuk Sekolah Dasar di Kecamanatan Nanggalo. Jurnal Kesehatan Andalas. 6 ( $3: 528)$

Pangalila, Y. V. Punuh M. I. \& Kapantow N.H. (2018) Hubungan Antara Riwayat Pemberian Asi Eksklusif Dengan Stunting Pada Anak Usia 6-24 Bulan di Wilayah kerja Puskesmas Koya Kabupaten Minahasa. Fakultas Kesehatan Masyarakat Universitas Sam Ratulangi Manado.

Patimah, S. (2017). Gizi Remaja Putri Plus 1000 Hari Pertama Kehidupan. Refika Aditama, Bandung 
Rahayuh, A. Yulidasari, F. Putri, A. O. Rahman, F. \& Rosadi, D. (2016) Faktor risiko yang berhubungan dengan kejadian pendek pada anak usia 6-24 bulan. Jurnal Kesehatan Masyarakat. 11 (2: 101)

Sumampouw, O. J. Soemarno. Andarani, S. \& Sriwahyuni, E. (2017) Diare Balita: Suatu Tinjauan dari Bidang Kesehatan Masyarakat. Deepublish. Yogyakarta.

Supariasa, I.D.N. Bakri, B. \& Fajar, I. (2017) Penilaian Status Gizi edisi 2. EGC, Jakarta.

Wahdah, S. Juffrie, M. \& Huriyati, E. (2015) Faktor Risiko Kejadian Stunting Pada Anak Umur 6-36 Bulan di Wilayah Pedalaman Kecamatan Silat Hulu, Kapuas Hulu, Kalimantan Barat. Jurnal gizi dan dietetik Indonesia. 3 ( $2: 128$ )

Wahyuningsih, R. (2013). Penatalaksanaan Diet pada Pasien. Graha IImu, Yogyakarta.

WHO. (2018) Reducing stunting In children. http://apps.who.int/ iris/ bitstream/ 106 65/260202/1/9789241513647-eng.pdf diakses pada 8 april 2018 